\title{
U.S. Geological Survey Continuous Monitoring Workshop-Workshop Summary Report
}

By Daniel J. Sullivan, John K. Joiner, Kerry A. Caslow, Mark N. Landers, Brian A. Pellerin, Patrick P. Rasmussen, and Rodney A. Sheets

Open-File Report 2018-1059

U.S. Department of the Interior U.S. Geological Survey 


\title{
U.S. Department of the Interior \\ RYAN K. ZINKE, Secretary
}

\section{U.S. Geological Survey \\ William H. Werkheiser, Deputy Director \\ exercising the authority of the Director}

\author{
U.S. Geological Survey, Reston, Virginia: 2018
}

For more information on the USGS—-the Federal source for science about the Earth, its natural and living resources, natural hazards, and the environment-visit https://www.usgs.gov/ or call 1-888-ASK-USGS (1-888-275-8747).

For an overview of USGS information products, including maps, imagery, and publications, visit https://store.usgs.gov/.

Any use of trade, firm, or product names is for descriptive purposes only and does not imply endorsement by the U.S. Government.

Although this information product, for the most part, is in the public domain, it also may contain copyrighted materials as noted in the text. Permission to reproduce copyrighted items must be secured from the copyright owner.

Suggested citation:

Sullivan, D.J., Joiner, J.K., Caslow, K.A., Landers, M.N., Pellerin, B.A., Rasmussen, P.P., and Sheets, R.A., 2018, U.S. Geological Survey continuous monitoring workshop-Workshop summary report: U.S. Geological Survey Open-File Report 2018-1059, 29 p., https://doi.org/10.3133/ofr20181059.

ISSN 2331-1258 (online) 


\section{Contents}

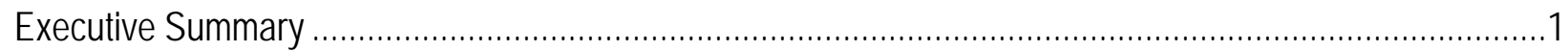

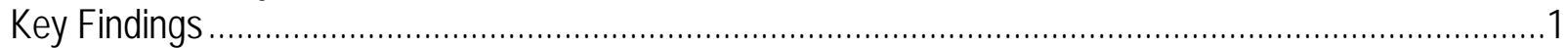

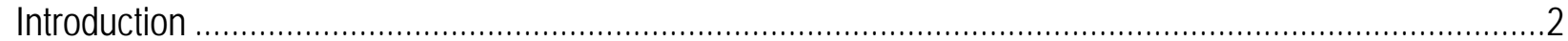

Theme 1: Collecting Continuous Data ..............................................................................................

Theme 2: Understanding and Using Continuous Data...................................................................

Theme 3: Observing and Delivering Continuous Data in the Future ..................................................13

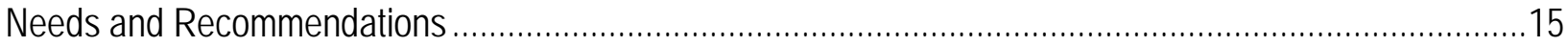

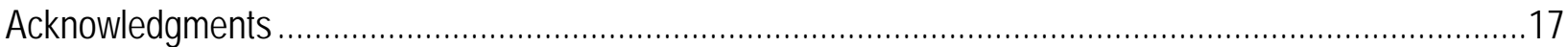

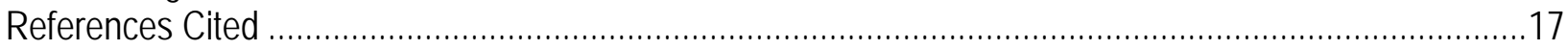

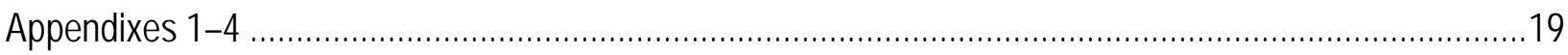

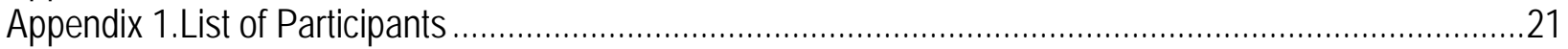

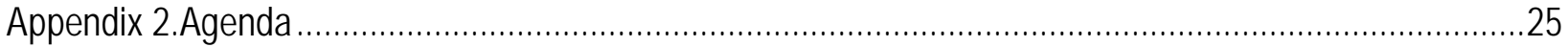

Appendix 3.Guidance Documents Pertinent to Continuous Monitoring ...................................................2

Appendix 4.Policy Memos Pertinent to Continuous Monitoring .........................................................28

\section{Figures}

Figure 1. The first multiparameter water-quality measurements began in 1959-60 when a water-quality monitor was installed in the Delaware River estuary at Philadelphia, Pennsylvania by the U.S. Geological Survey (USGS) to track rapidly changing water temperature and salinity (Durum, 1978). The USGS tested and made innovative improvements to monitoring equipment for the next several years in cooperation with the City of Philadelphia and equipment manufacturers. (Photograph: USGS; on left is Norm Beamer, District Chief, Philadelphia, Pennsylvania and on the right is David McCartney, Chemist, USGS Philadelphia) ........................... 4 Figure 2. Example equipment installation on streambank for multifaceted monitoring programs of the U.S. Geological Survey-South Atlantic Water Science Center Urban Hydrology projects includes instrumentation to record stream-stage and water-quality measurements and collect water samples . (Photo: USGS)....................... 5 Figure 3. Seismic activity reflected in water-level measurements in monitoring well VW-1, Ohio. Seismic-wave arrivals are for the seismic station near VW-1.

Figure 4. Predicted groundwater-discharged (GWD) and runoff (RO) loads for nitrate (NO2) loads at $A$, Potomac River near Washington D.C., B, Smith Creek, Virginia, and C, Difficult Run, Virginia. Precipitation events mobilize nitrate that is stored in groundwater. This groundwater-discharged nitrate contributes to the stream for weeks to months following high-flow events (from Miller and others, 2016).

Figure 5. In the Grand Canyon, floods on tributaries below the Glen Canyon Dam introduce large sediment volumes over short periods of time, independent of main-stem flows. These photos were taken a few hours and miles apart in upper Marble Canyon. (Photographs by David Topping, U.S. Geological Survey) ....

Figure 6. Schematic showing a typical integrated survey with a manned boat equipped with an acoustic Doppler current profiler (ADCP) and a differential global positioning system (GPS) receiver and the autonomous underwater vehicle equipped with a suite of water-quality sensors, ADCP and Doppler velocimetry log, and sidescan sonar. The three primary survey modes (constant depth, constant height above bottom, and undulation) are shown for the autonomous underwater vehicle (from Jackson, 2013).. 


\section{Table}

1. Useful resources for scientific computing and graphics........................................................12

\section{Conversion Factors}

U.S. customary units to International System of Units

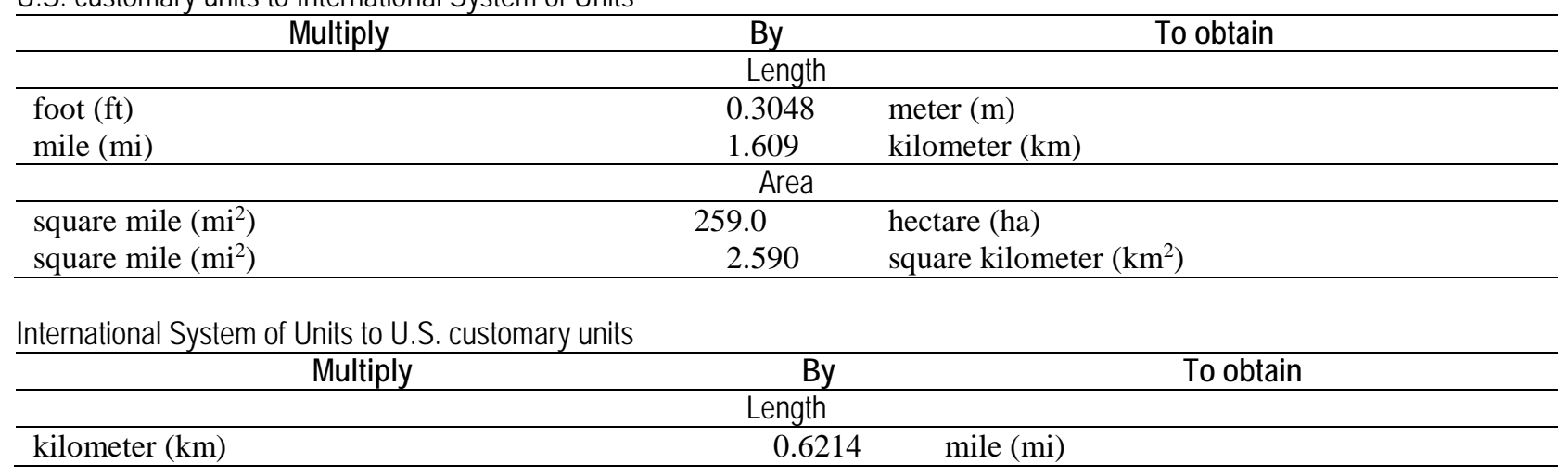

\section{Supplemental Information}

Concentrations of chemical constituents in water are given in either milligrams per liter $(\mathrm{mg} / \mathrm{L})$ or micrograms per liter $(\mu \mathrm{g} / \mathrm{L})$.

\section{Abbreviations and Acronyms}

$\begin{array}{ll}\text { ADCP } & \text { Acoustic Doppler Current Profiler } \\ \text { ADVM } & \text { acoustic Doppler velocity meter } \\ \text { AUV } & \text { autonomous underwater vehicles } \\ \text { CDOM } & \text { Colored or chromophoric dissolved organic matter } \\ \text { EDNA } & \text { environmental deoxyribonucleic acid } \\ \text { FDOM } & \text { fluorescent dissolved organic matter } \\ \text { GPS } & \text { Global Positioning System } \\ \text { QA } & \text { quality assurance } \\ \text { QW } & \text { water quality } \\ \text { R } & \text { an open-source language and environment for statistical computing and graphics } \\ \text { SSC } & \text { suspended-sediment concentration } \\ \text { USGS } & \text { U.S Geological Survey } \\ \text { UV } & \text { ultraviolet } \\ \text { WSC } & \text { Water Science Center } \\ \text { WSFT } & \text { Water Science Field Team }\end{array}$




\section{U.S. Geological Survey Continuous Monitoring Workshop-Workshop Summary Report}

By Daniel J. Sullivan, John K. Joiner, Kerry A. Caslow, Mark N. Landers, Brian A. Pellerin, Patrick P. Rasmussen, and Rodney A. Sheets

\section{Executive Summary}

The collection of high-frequency (in other words, “continuous”) water data has been made easier over the years because of advances in technologies to measure, transmit, store, and query large, temporally dense datasets. Commercially available, in-situ sensors and data-collection platformstogether with new techniques for data analysis-provide an opportunity to monitor water quantity and quality at time scales during which meaningful changes occur. The U.S. Geological Survey (USGS) Continuous Monitoring Workshop was held to build stronger collaboration within the Water Mission Area on the collection, interpretation, and application of continuous monitoring data; share technical approaches for the collection and management of continuous data that improves consistency and efficiency across the USGS; and explore techniques and tools for the interpretation of continuous monitoring data, which increases the value to cooperators and the public. The workshop was organized into three major themes: Collecting Continuous Data, Understanding and Using Continuous Data, and Observing and Delivering Continuous Data in the Future. Presentations each day covered a variety of related topics, with a special session at the end of each day designed to bring discussion and problem solving to the forefront.

The workshop brought together more than 70 USGS scientists and managers from across the Water Mission Area and Water Science Centers. Tools to manage, assure, control quality, and explore large streams of continuous water data are being developed by the USGS and other organizations and will be critical to making full use of these high-frequency data for research and monitoring. Disseminating continuous monitoring data and findings relevant to critical cooperator and societal issues is central to advancing the USGS networks and mission. Several important outcomes emerged from the presentations and breakout sessions.

\section{Key Findings}

On the basis of presentations, breakout-group discussions, and other discussions among workshop participants, we have identified several key findings:

1. The workshop revealed that the advancement of continuous monitoring science across the USGS has an organic, dispersed, and often disparate character. While the workshop was a step towards improved collaboration across disciplines and functions (observing, predicting, interpreting, and disseminating), there remains a need for better coordination and leadership within and across the disciplines and functions. Providing highly relevant information products that leverage our continuous monitoring expertise across USGS networks and people can only be fully realized by continuing collaboration across the bureau. 
2. The cost and the resources available for the task are limiting factors to be balanced during consideration of moving emerging technologies from research to operation and for creating networks and information products.

3. Web-information delivery tools and software are substantial limiting factors to delivering national-level information products that connect continuous monitored data (including uncertainty and spatial relationships) in a form that is readily understood and usable to cooperators and the public.

4. Tools for analysis and storage of very large amounts of data and metadata collected with new continuous monitoring technologies have been developed, but not always as quickly as the datacollection technology, and that is a challenge for users. The USGS's recent adoption of a modern database and database management system to process real-time data (AQUARIUS) is a major help to workflows, but more needs to be done.

5. Defined program development initiatives (and resources) are needed to leverage and connect existing and emerging monitoring technologies and networks to create continuous temporal and spatial information tools (including modeling and prediction).

\section{Introduction}

The collection of high temporal frequency (for example “continuous”) water data has been made easier to accomplish over the years through advances in technologies to measure, transmit, store, and query large, temporally dense datasets. The U.S. Geological Survey (USGS) Continuous Monitoring Workshop was convened to facilitate the technical exchange of ideas and best practices related to the collection and interpretation of continuous data within the USGS Water Mission Area (WMA), including streamflow, water-quality, water-level, and sediment data. Attendees shared surface water and groundwater data-collection methods, explored techniques for interpreting continuous data, and discussed how to facilitate further innovation within the WMA that will improve our ability to deliver mission critical data to the public.

The 3-day workshop (June 27-29, 2017) on continuous monitoring was jointly convened by the USGS Office of Water Quality, Office of Surface Water and Office of Groundwater and took place at the South Atlantic Water Science Center in Norcross, Georgia. The workshop brought together more than 70 scientists, technicians, and program managers from across the USGS (appendix 1).

The workshop had three major goals:

- Build stronger collaboration within WMA on the collection, interpretation, and application of continuous monitoring data;

- Share technical approaches for the collection and management of continuous monitoring data that improves consistency and efficiency across the USGS; and

- Explore techniques and tools for the interpretation of continuous monitoring data that increases its value to cooperators and the public.

Presentations from the workshop demonstrated many of the recent advances, current challenges, and new opportunities associated with continuous monitoring of water quantity and quality in surface water and groundwater. Talks were organized by theme, and they provided examples and context for the collection and use of continuous monitoring data. Additional sessions provided hands-on technology demonstrations and group discussions. 


\section{Theme 1: Collecting Continuous Data}

Presentation topics for the first day of the workshop (appendix 2) included the history of continuous monitoring, an example of the role of continuous monitoring in program development, verifying and improving instrument performance and development, and an overview of policies and guidance for continuous monitoring data collection. The day concluded with a demonstration of timeseries workflows in the new AQUARIUS software package as well as hands-on demonstrations of a variety of technologies and applications. Summaries of the presentations are included here, beginning with an overview of the evolution of continuous monitoring.

The history of continuous monitoring for water quality begins in the laboratory, because most of today's field-sensor technologies were developed from instruments used in physical, chemical, biomedical, and water-testing laboratories. A revolution in water-chemistry analysis took place with the development of advanced physical instrumentation that began in the 1930s.. This affected water analysis in three ways: (1) new types of analytical instruments expanded the ability to detect a wide variety of chemical compounds using small amounts of sample; (2) the time needed for analysis was reduced and precise measurements became possible; and (3) with each passing decade from 1930 to 1975, the detection capabilities of new analytical instruments improved by about an order of magnitude or more (Travis, 2002; Myers, 2015). Detection limits decreased from tens of milligrams per liter in 1890 to tenths of micrograms per liter by 1950. These laboratory instruments gave rise to instruments that could be taken to the field to collect in situ measurements.

The earliest field sensors were glass electrode $\mathrm{pH}$ sensors; today, optical sensors have opened new fields of inquiry to the application of sensor technology. In the early days, scientists carried the sensor to the field and recorded readings on paper. Today, field installations (an early example is shown in fig. 1) deploy sensors that supply near-real-time information via satellite and modem, and autonomous underwater vessels can be programmed to survey large areas of waterbodies in mere hours.

Along with advances in instrumentation, data collection and storage systems have advanced from analog (strip charts) to computer punch tapes to automated digital recorders. Data retrieval and transmission have evolved as well. At one time, the only way to get data was to physically visit a site. Eventually, data could be transmitted, first by teletype, then radio, land line, cell phone, and satelliterelay systems. Along with these improvements, the timeliness of data dissemination has improved from periodic updates to being available in near-real-time on the internet. 


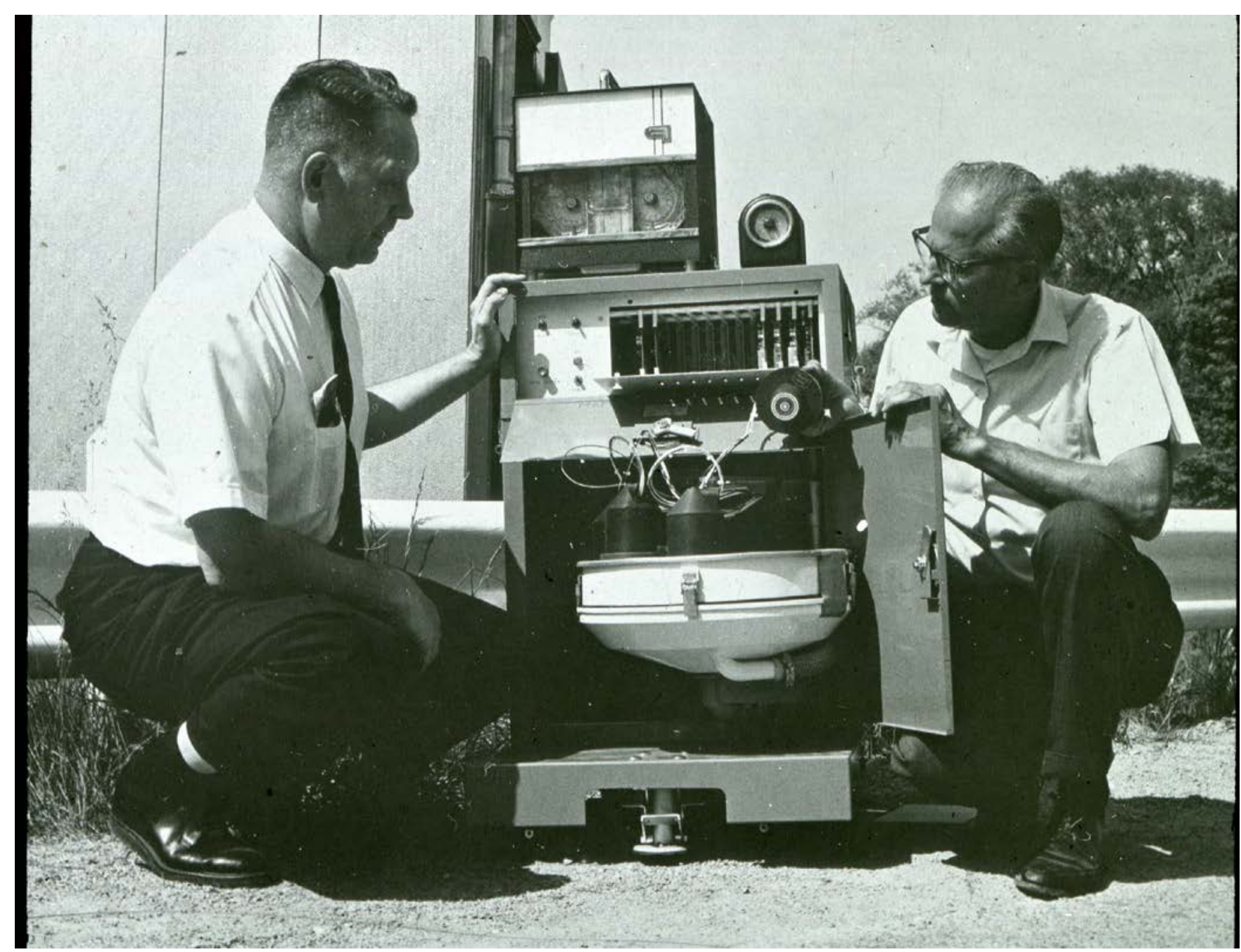

Figure 1. The first multiparameter water-quality measurements began in 1959-60 when a water-quality monitor was installed in the Delaware River estuary at Philadelphia, Pennsylvania by the U.S. Geological Survey (USGS) to track rapidly changing water temperature and salinity (Durum, 1978). The USGS tested and made innovative improvements to monitoring equipment for the next several years in cooperation with the City of Philadelphia and equipment manufacturers. (Photograph: USGS; on left is Norm Beamer, District Chief, Philadelphia, Pennsylvania and on the right is David McCartney, Chemist, USGS Philadelphia)

The role of continuous monitoring in program development was illustrated in a discussion of urban studies in the Atlanta metropolitan area, where a variety of projects with major cooperators were using continuous monitoring to extend their capabilities. With the base streamgaging program in place with its near-real-time reporting, the cooperators' need for water-quality and weather information could be met, in many cases, by adding appropriate equipment to existing infrastructure (fig. 2). Cooperators asked USGS to assist them in identifying water-quality trends, predicting flood-inundation potential, and identifying sources and magnitudes of pollutants. As the individual programs grew, USGS management recognized parallel interests among them, as well as an opportunity to further grow and expand programs by increasing USGS science excellence and leadership under the umbrella of an "Urban Hydrology" team. Thus brought together, the team has continued to increase its technical 
competency and leverage knowledge gained on projects to help grow projects in other parts of the metro area.

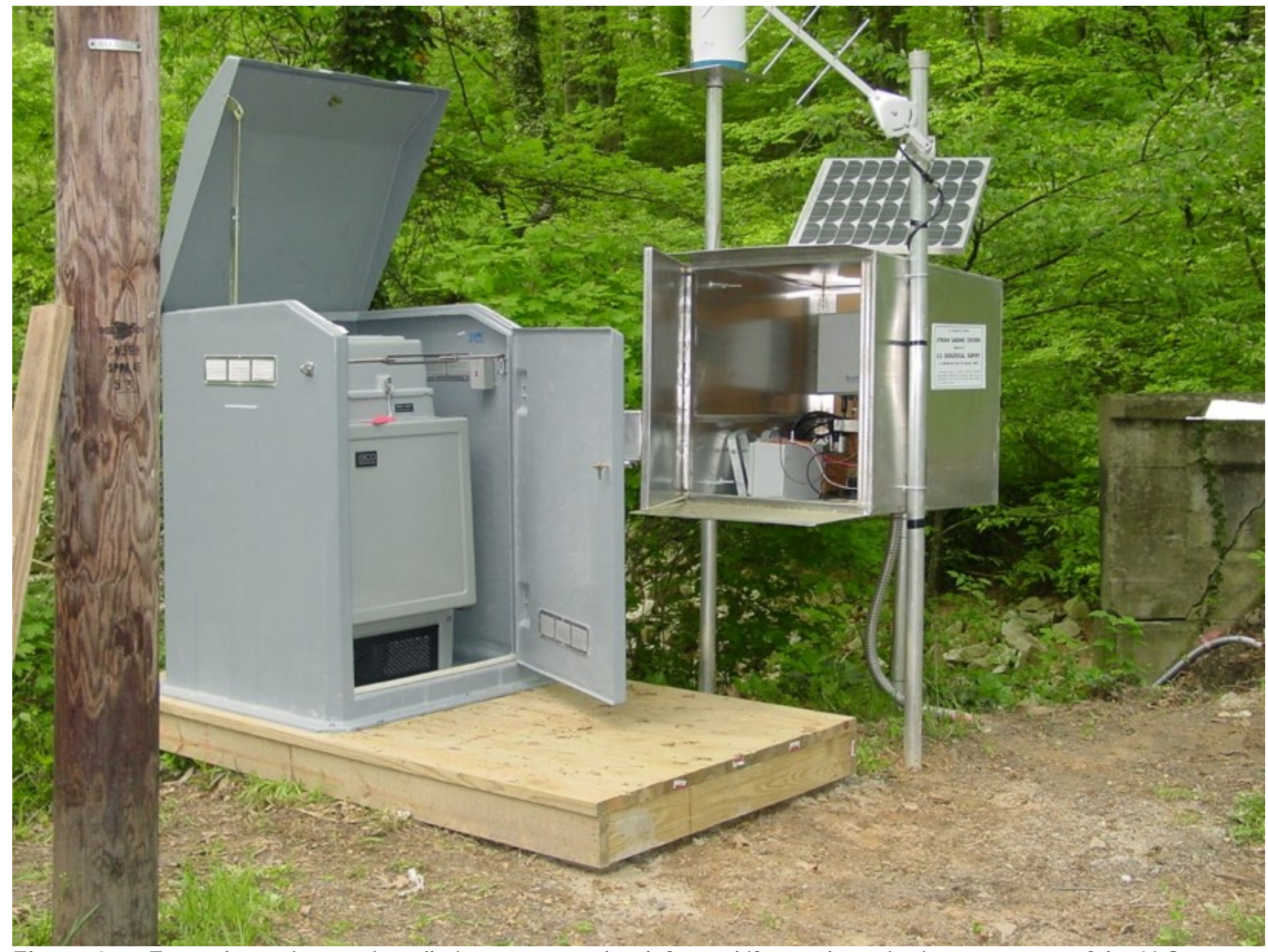

Figure 2. Example equipment installation on streambank for multifaceted monitoring programs of the U.S. Geological Survey-South Atlantic Water Science Center Urban Hydrology projects include instrumentation to record stream-stage and water-quality measurements and collect water samples. (Photograph: USGS)

Verification and improvement of instrument performance and development is an approach that researchers, working together with instrument makers, can use to meet goals when instrumentation exists but the data produced may fall short of required or desired program goals. Hydroacousticinstrumentation field-validation testing is an example of an extensive and successful comprehensive quality assurance (QA) program.

With the introduction of hydroacoustic instruments in the early 1990s, USGS researchers saw the opportunity to not only collect streamflow data more efficiently and accurately, but to further use the ancillary data collected to answer other questions. Because every acoustic Doppler current profiler (ADCP) measurement contains high-resolution three-dimensional velocity, depth, and backscatter (signal strength) data, there are a host of other purposes for the data collected by these instruments. However, systematic programs for validating acoustic instruments for streamflow and other measurements have not been well documented. 
The components of a QA program include acceptance testing, routine QA, postrepair testing, and publications on field testing (Oberg and Mueller, 2007). Today more than 80 percent of USGS discharge measurements are made with an acoustic device. In other words, the USGS has almost completely changed the technology used for streamgaging from mechanical devices to acoustic instruments, software, and methods in just over 15 years.

Comprehensive field validations are expensive and can be hard to do, but they are essential to the QA of instruments particularly for identifying biases. In the case of hydroacoustic instruments, and other field instrumentation, issues with equipment are identified and addressed by means of technical support requests and feedback from the field. "Instrument testing" is much more than bench testing new instruments; it is also recognizing possibilities for refinements and enhancements that can be made through slight modifications of the equipment. The ability of the USGS to influence product development through our interaction with instrument manufacturers is extremely important to the future of the USGS and other entities involved in environmental monitoring. When combined with a good working relationship with manufacturers, instrument testing in a variety of conditions, from controlled laboratory conditions to complex and extreme field conditions, can result in improved performance.

The evolution of guidance and policies for continuous monitoring, from the proposal stage through data archival, began around 1980. Prior to that time, there were no guidance documents or policies on data QA and processing for continuous monitoring. Most publications in the USGS Techniques and Methods series are updated through time as instrumentation and methods are updated. Current USGS publications for operation and maintenance, and for surrogates, are listed in appendix 3. Policies and memos applicable to continuous monitoring are listed in appendix 4.

The afternoon featured a demonstration on time-series workflows in AQUARIUS and hands-on demonstrations of continuous monitoring technologies by USGS staff.

\section{Theme 2: Understanding and Using Continuous Data}

Day two of the workshop began with a welcome from the Director of the host Water Science Center followed by a diverse series of presentations on understanding and using continuous monitoring data (appendix 2). Topics covered included collecting and interpreting physical measurements in groundwater, interpreting continuous water-quality data to identify drivers and processes for dissolved constituents, monitoring suspended sediment and bedload to evaluate the physical processes that control sediment movement in estuaries, and developing and using water-quality surrogate models. In addition, a team of software developers presented information on tools that have been developed and are under development that could be useful. Finally, the day concluded with 5-minute lightning talks that highlighted projects across the USGS.

Collecting and interpreting physical measurements in groundwater may be overlooked by some $_{2}$ as groundwater is often viewed as a slowly changing environment where continuous waterquality monitoring is of little value. However, continuous monitoring of groundwater levels is commonplace and used in many applications. Examples of some of the useful information that can be gleaned from various frequencies of continuous monitoring of water levels (fig. 3). Although highfrequency monitoring (less than a minute) is somewhat specialized, there may be emerging applications for its increased use in continuous monitoring of water levels. 


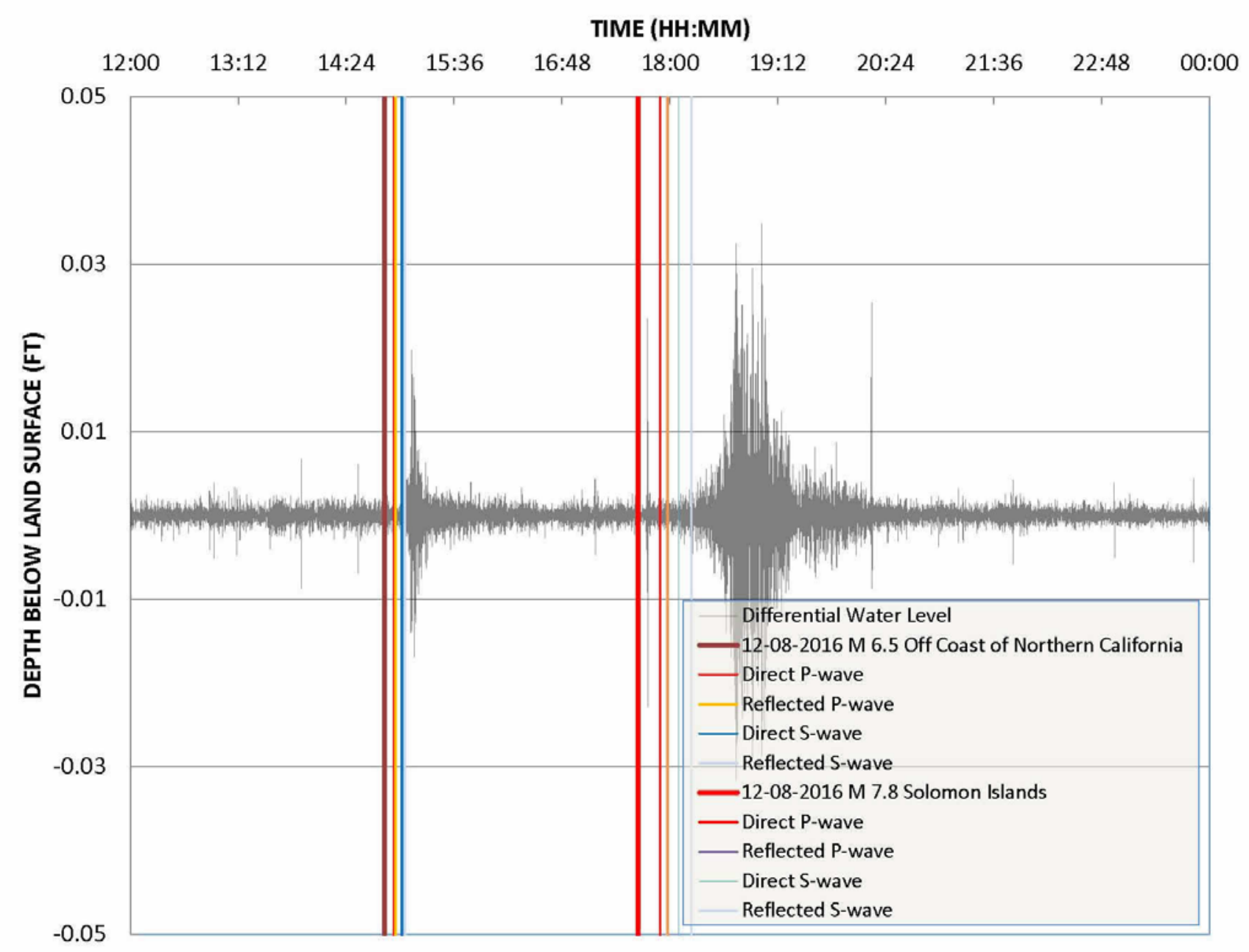

Figure 3. Seismic activity reflected in water-level measurements in monitoring well VW-1, Ohio. Seismic-wave arrivals are for the seismic station near VW-1.

Existing groundwater-level data from confined aquifers often have Earth tides, or displacement of the solid Earth's surface caused by the gravity of the Sun and the Moon, and analysis of these data can be used to determine aquifer properties on a large scale. An example use for existing network data included raw water-level data and barometric-pressure data from nearby National Oceanic and Atmospheric Administration sites; barometric pressure was then used to correct the raw water-level data. The Earth tides were analyzed by a program written to calculate the effects of Earth tides and extract specific storage and porosity data. Examples of high-frequency groundwater-level data that were shown from across the United States exhibited responses from worldwide earthquakes that might be used to calculate aquifer properties.

The presentation not only demonstrated the value of high-frequency groundwater-level data but also served as an example of how data already being collected in our networks can potentially be mined, and innovative techniques from other fields could be applied to analyze these data. As instrumentation gets better, higher frequency data can potentially be used to analyze processes that we never could study before.

A new approach for interpreting continuous water-quality data to identify drivers and processes for dissolved constituents was presented by researchers in the Chesapeake Bay watershed. 
Hydrograph separation is combined with high-frequency nitrate data to quantify time-variable groundwater and runoff loading of nitrate to streams, and the net instream fate of nitrate at the watershed scale. This approach furthers researchers' ability to understand, predict, and mitigate nitrate impacts on streams and receiving waters by providing insights into temporal nitrate dynamics that would be difficult to obtain using traditional field-based studies (fig. 4; from Miller and others, 2016). Legacy nitrate sources and transport are critical to understanding the effects of conservation efforts in the Chesapeake Bay watershed. Identifying flow paths by which water and nitrate are discharged to streams is important with respect to establishing management strategies and defining the time period in which results may be expected. 

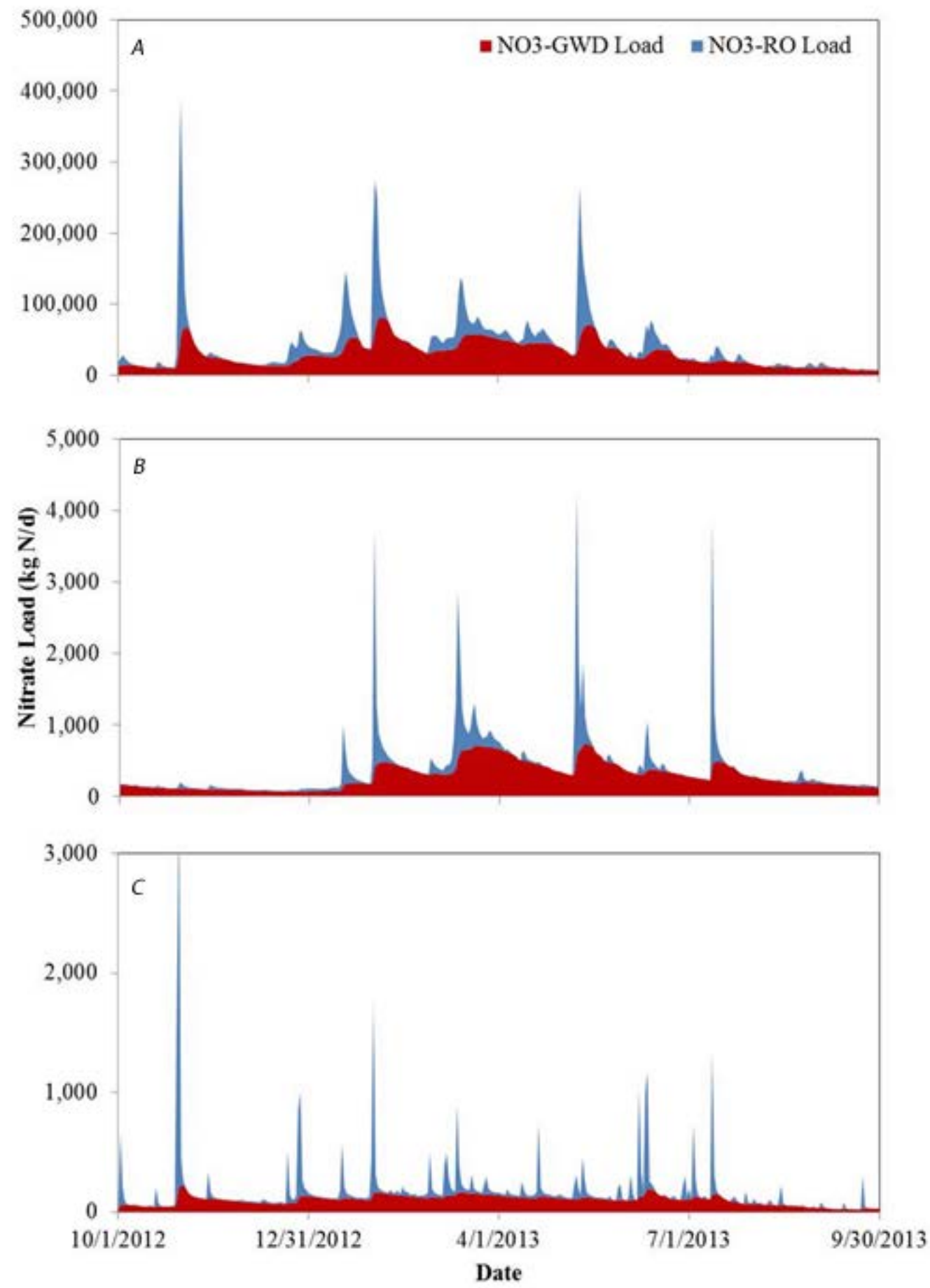

Figure 4. Predicted groundwater-discharged (GWD) and runoff (RO) loads for nitrate (NO3) loads at $A$, Potomac River near Washington D.C., B, Smith Creek, Virginia, and C, Difficult Run, Virginia. Precipitation events mobilize nitrate that is stored in groundwater. This groundwater-discharged nitrate contributes to the stream for weeks to months following high-flow events (from Miller and others, 2016). 
A study of water supply and demand in the semiarid Colorado River Basin developed new methods and understanding to quantify the connection between groundwater and surface water. The approach used was to estimate groundwater discharge to streams at a limited number of sites using continuous monitoring data, estimate groundwater discharge to streams at a large number of sites using discrete water-quality data, and then use discrete data estimates as calibration data in a SPAtially Referenced Regressions On Watershed attributes (SPARROW) model to derive spatially-distributed estimates of groundwater discharge to streams (Miller and others, 2014). Continuous specific conductance data were collected to estimate groundwater discharge to streams. Streamflow and chemical composition data were used to separate streamflow into runoff and groundwater components. Results suggest that reservoirs may act to store base flow discharged to the stream during snowmelt and release that base flow during low-flow conditions, and that irrigation return flows may contribute to increases in fall base flow in heavily irrigated watersheds. The chemical hydrograph separation approach and associated conceptual model defined here provide a basis for the identification of land use, management, and climate effects on base flow.

Evaluating the physical processes that control sediment movement in rivers and estuaries with data collected by traditional methods (bottle or bag sampling with laboratory analysis followed by computation of daily records) is time-consuming and expensive, and relevant time scales are difficult to capture. In the field of geomorphology, the concept of discharge controlling sediment transport has been around for a long time and has been useful in many ways. Continuous monitoring has removed many limitations of traditional sampling and provided the tools to improve our understanding of the controls on sediment transport.

Sediment particles and their movement can be measured and calibrated to traditional sampling data. Continuous monitoring methods include optical measurements of turbidity and acoustic properties such as backscatter and attenuation.

In the Grand Canyon, floods on tributaries below Glen Canyon dam introduce large sediment volumes over short periods of time, independent of main-stem flows (fig. 5; from Topping and Wright, 2016). Side-looking Doppler profiles discriminate fines from sand and track changes in sand-grain size, while not relying on a correlation with discharge, and this is critical to understanding the dynamics in a system where small tributaries contribute the bulk of sediment loads.

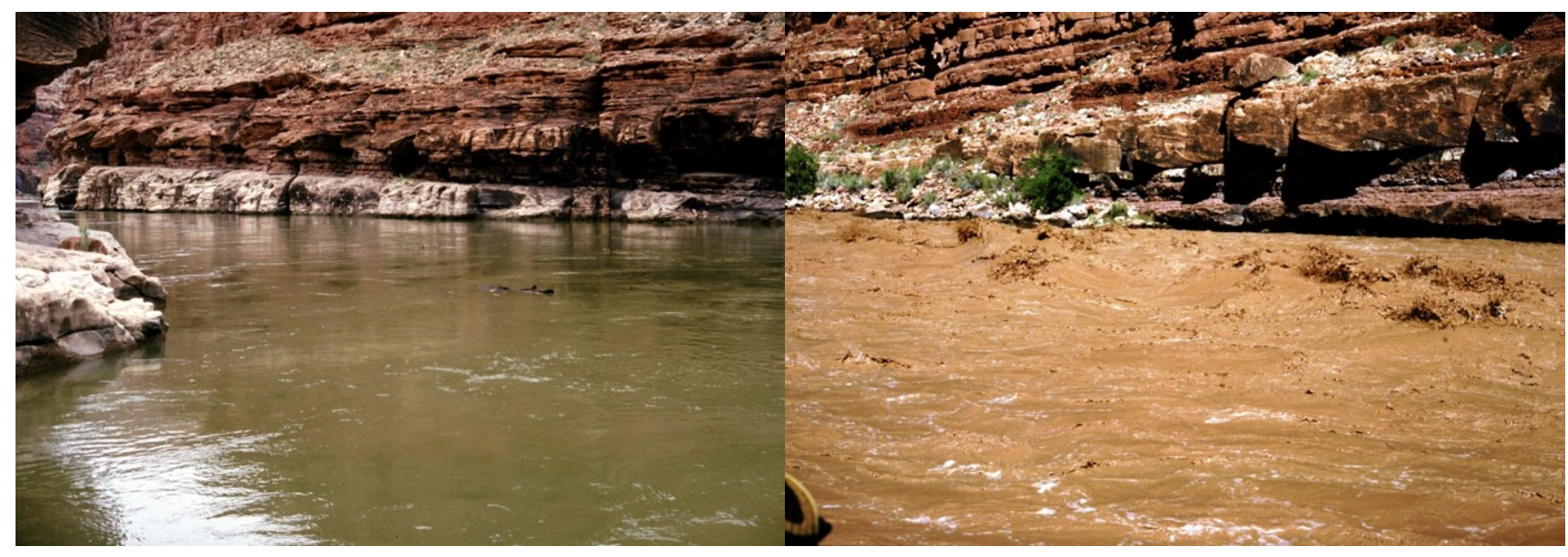

Figure 5. In the Grand Canyon, floods on tributaries below the Glen Canyon Dam introduce large sediment volumes over short periods of time, independent of main-stem flows. These photos were taken a few hours and miles apart in upper Marble Canyon. (Photographs by David Topping, U.S. Geological Survey) 
Bedload transport in gravel-bedded rivers exhibits substantial spatial variability in transport rates linked to geomorphic features (such as pools and riffles). Continuous monitoring with hydrophones from a moving platform offers a unique ability to measure this variability. Researchers floated a 20-kilometer reach of the Trinity River in California for three flows when gravel transport was active, measuring transport rates (as a function of discharge) along the reach with hydrophones, an acoustic Doppler current profiler, and a global positioning system. By using this approach, they identified 54 individual pool-riffle sequences over the reach. These data can be used to illustrate the mechanisms that maintain pools and riffles. It is the first time that these mechanisms have been measured, because it is not possible with traditional sampling.

Developing and using water-quality surrogate models enables estimation of concentrations and loads of constituents when direct measurement is too difficult or expensive. Direct measurements of water quality using sensors (specific conductance, turbidity, dissolved oxygen, $\mathrm{pH}$, water temperature, and others) are used as surrogates for constituents of particular interest that cannot easily be measured directly (sediment, dissolved solids, nutrients, indicator bacteria). The USGS began working with continuous surrogate methods around 2000 with work in Kansas and Oregon (Christensen and others, 2000 — sediment, chloride, bacteria, atrazine; Christensen and others, 2001—sediment, major ions, nutrients, pesticides, bacteria; Uhrich and Bragg, 2003—sediment).

The principle of water-quality surrogate models is similar to that of stage-discharge ratings - a regression-based approach made possible by the availability of reliable, "low" maintenance sensors designed for long-term deployment. The tool for data dissemination, Near Real Time Water Quality or National Real-Time Water Quality (https://nrtwq.usgs.gov/) was developed in support of surrogate models in order to display the data.

There are a host of applications for surrogate models, and more continue to be developed. Consistent methods for computing suspended-sediment concentrations (SSC), the most common surrogate constituent, were developed to streamline the process for continuous turbidity and streamflow to estimate SSC (Rasmussen and others, 2009) and to use acoustic Doppler velocity meter backscatter data to compute SSCs (Landers and others, 2016). A methods report is in progress as well as policy guidance for the most common regression approach being used-linear (and log-linear) models using unit-value surrogate data to compute unit-value water-quality concentration data. The approach is generally consistent with the sediment surrogate Techniques and Methods report (Landers and others, 2016) and policy, except there are more statistical details and explanations. Also, an R package for model exploration and development is being tested.

Many scientific computing and graphics software tools for USGS scientists are available in the R statistical programming language. Although there are numerous packages developed specifically by USGS scientists (table 1), the usefulness of these tools can be easily expanded due to the inherent accessibility of an open-source code like R. Several stream-metabolism examples were discussed as an area with high potential for application in many parts of the United States. 
Table 1. Useful resources for scientific computing and graphics.

[USGS, U.S. Geological Survey; OWI, Office of Water Information; R, an open-source language and environment for statistical computing and graphics; NWIS, National Water Information System; WQP, Water Quality Portal]

The Comprehensive R Archive Network (CRAN)

- $\quad$ https://cran.r-project.org

U.S. Geological Survey R Archive Network (GRAN)

R-package catalogs

- $\quad$ https://owi.usgs.gov/R/index.html (.gov address for USGS software distribution)

Other package catalogs

- Bioconductor: https://www.bioconductor.org

- ROpenSci: https://ropensci.org/packages

- GitHub: https://github.com

USGS training (OWI Data Science)

- Intro to scientific computing in R-https:/owi.usgs.gov/R/training.html

- Specific USGS R packages-https://owi.usgs.gov/R/training-curriculum/usgs-packages/

Non-USGS: Learning R

- http://swirlstats.com

- $\quad$ http://tryr.codeschool.com

Learning resources

- https://www.datacamp.com

- $\quad$ http://www.datacarpentry.org

Non-USGS: Specific issues and advanced topics

- $\quad$ Analysis best practices: Wilson and others, 2017

- https://stackoverflow.com

- https://ropensci.org

- $\quad$ https://cran.r-project.org/web/views/TimeSeries.html

Data retrieval tools:

- In-situ data-NWIS and WQP (dataRetrieval)

- $\quad$ Gridded data-climate, land use, and population (geoknife)

Data analysis tools (domain-specific models):

- streamMetabolizer,

USGS R tools

- EflowStats,

- Exploration and Graphics for RivER Trends (EGRET),

- loadflex,

- GRAN

Reporting tools:

- Data release in ScienceBase (sbtools) 


\section{Theme 3: Observing and Delivering Continuous Data in the Future}

The third day of the workshop was intended to identify emerging technologies, approaches, and needs for the future collection and use of continuous monitoring data. The presentations on day three (appendix 2) provided examples of new approaches to data collection and a vision for the storage and usage of continuous data in visualizations.

A vision for future directions of the USGS WMA, focusing on critical data needed by water managers and the public to make informed decisions on water resources, was presented by the USGS Associate Director for Water. The integration of field observations into models will continue to be a priority, given the complex spatial and temporal needs for water data. Consequently, there is a need to better integrate many types of data into models, thus building a foundational capacity for the future modeling across any mission areas.

To evaluate and support the use of emerging technologies and facilitate the integration of sensor data into models, the USGS Branch of Geophysics conducts technology development, training, and other various forms of assistance on a variety of instruments and techniques. Although there will always be a need for discrete field sampling, modeling and predictive systems make continuous records of data with low latency and high temporal resolution important. Strategies for combining real-time data with sophisticated modeling on a much wider scale than used currently are needed for comprehensively developing models for wider areas. New technologies help USGS scientists characterize sites using seismic and borehole techniques, aquifer structure, and other techniques. Other emerging technologies, such as the ability to measure environmental DNA (eDNA) in situ and in near-real time, as an indicator of the presence of invasive species and pathogens, requires continued investment into consistent use and reporting for broader USGS applications.

The use of mobile sensors to fill spatial data gaps will also continue to be a critical need, even though most work to collect continuous data has focused on filling the temporal gaps between discrete samples on fixed sites. Mobile sensor platforms are also useful for the collection of spatially and temporally dense data, effectively filling the gaps between fixed sites. Sensors can be mounted on any number of moving vessels to provide spatial data, including vessels at the surface (kayaks, trimarans, and remote-controlled boats) and autonomous underwater vehicles (AUVs). AUVs can be preprogrammed to collect data throughout a water body, providing details on water properties with depth in the water column (fig. 6). Examples of data collected by AUV and boat-mounted sled demonstrate the benefits of continued investment in these technologies for continuous data collection (Jackson and Reneau, 2014; Vonins and Jackson, 2017). 


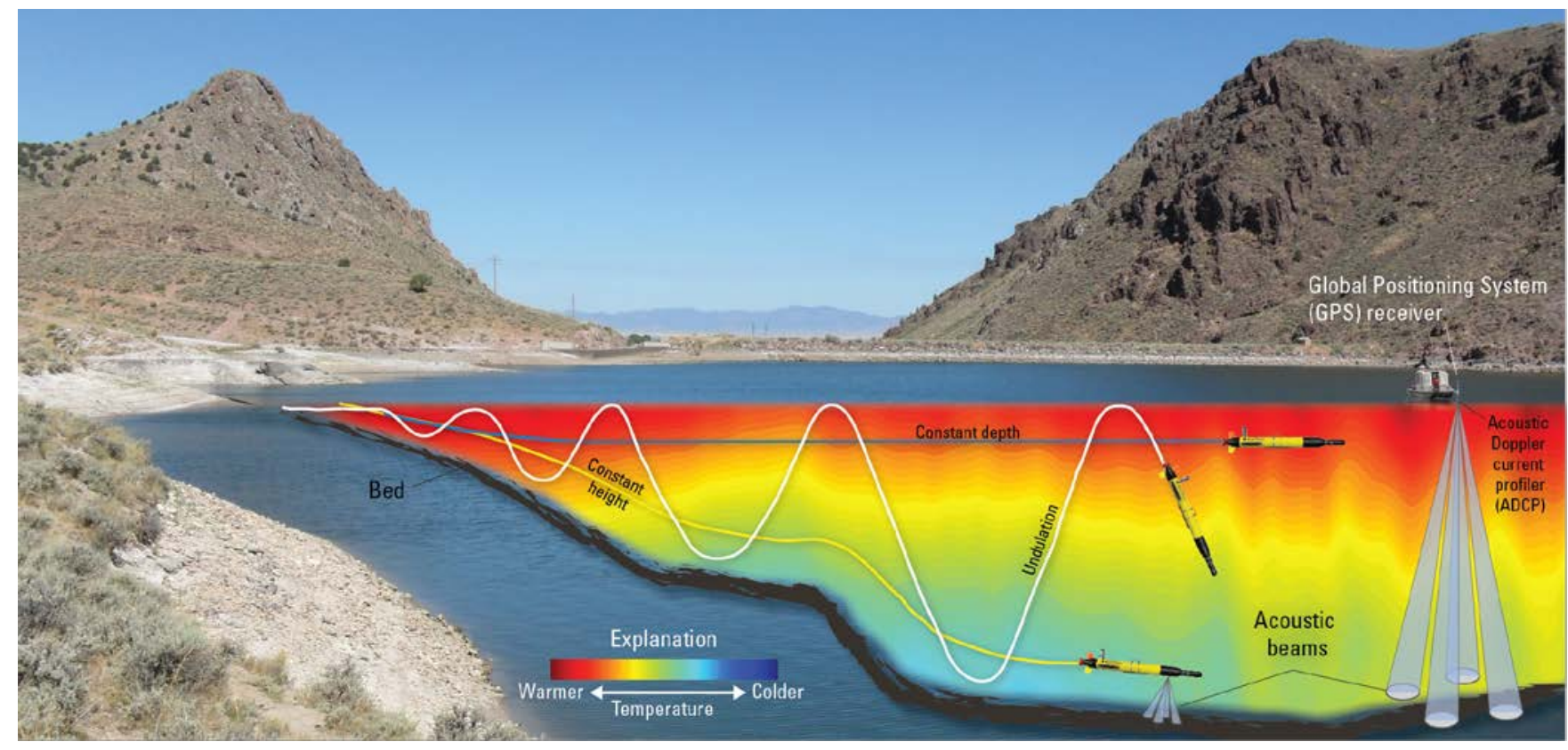

Figure 6. Schematic showing a typical integrated survey with a manned boat equipped with an acoustic Doppler current profiler (ADCP) and a differential global positioning system (GPS) receiver and the autonomous underwater vehicle equipped with a suite of water-quality sensors, ADCP and Doppler velocimetry log, and side-scan sonar. The three primary survey modes (constant depth, constant height above bottom, and undulation) are shown for the autonomous underwater vehicle (from Jackson, 2013).

Integrated monitoring in response to harmful algal blooms is a primary example of the integration of various types of field and laboratory data with models for understanding and responding to complex water challenges. Although not all algal blooms are harmful, and not all harmful blooms are toxic, impacts range from those with economic consequences, to beach closures, to serious impacts on human and ecological health. USGS researchers are studying algal blooms across a range of ecosystem types throughout the nation, using a variety of approaches including satellite data, near-surface imagery, discrete sample collection, and in situ sensors. Simple approaches, such as the use of remote time-lapse cameras or fluorescence sensors, have potential as early warning systems for the presence and location of blooms. Fluorescence sensors that measure optical properties of the water that are often proportional to the abundance of algal material can also be used to identify the presence of harmful algal blooms. However, the integration of remote sensing, in situ observations, and discrete sampling for a variety of compounds will be critical for understanding and modeling the factors leading to bloom formation and their associated toxicity.

Innovations in data science will be required for managing and serving continuous data from a wide variety of instruments, data types, and locations. For example, the next generation of the USGS National Water Information System (NWIS) is an example of a platform that will need to be designed to handle diverse site types and time-series dense data, as well as supporting better data documentation. Water-data paradigms are shifting away from the familiar datasets of continuous and discrete samples collected from a site or uniform grid, to a new array of data types and locations. These new data types include eDNA data, which can be thought of as taking a census of the wild with a jar, because eDNA data from multiple organisms can be collected in a single sample container; data from sensors mounted to moving vehicles or frames of reference (unmanned vehicles, Lagrangian, structure from motion); and footprint or integrator measurements (environmental exposure/duration, passive samplers). Scientist 
experts in the domain may not understand where the limits of data and technology lie, thus creating a need for the technologist, or data scientist, to help solve data integration challenges, create solutions that turn raw data into decision-ready research workflows, and distill large, complex data into useful information.

\section{Needs and Recommendations}

The needs and recommendations detailed in the following section resulted from presentations given by workshop participants, breakout-group discussions, and other discussions among workshop participants. These needs and recommendations cover the continuous data gamut, from collecting it to understanding and using it to observing and delivering it in the future. There are a number of recurring needs and recommendations that came up during the course of the workshop. This section is an attempt to distill and organize them into six needs for future discussion.

1. Reducing the cost of continuous data collection and management. The cost of continuous monitoring has been a challenge since the first sensors were deployed given the need for sensors, data collection and transmission platforms, and data management software. The infrastructure costs - along with personnel needs - can be a roadblock for some projects. And while sensors continue to be refined and made more reliable, field deployments continue to pose challenges for users. For example, biofouling is a challenge in many freshwater and coastal systems that is often difficult to recognize remotely and requires vigilance from the field technicians on a near daily basis. Recommendation: While the increased use of continuous monitoring technologies will likely result in lower cost sensors and greater efficiencies in operation, information sharing of solutions is one way to help new adopters get up to speed, quickly share information to a broad range of users, and "crowdsource” solutions. Workshop participants, therefore, recommend that options for online continuous monitoring forums be investigated and perhaps modeled after successful USGS (for example, the Hydroacoustics Workgroup forum) or external forums to quickly and broadly share questions and answers related to continuous water monitoring.

2. Further demonstrate the value of continuous monitoring using existing data. Continuous monitoring often is not always used to its fullest potential. For example, the USGS collects and publishes water temperature data from over 2,000 gages nationwide in real time, yet few studies have systematically evaluated the use of the data at local to national scales by recreational users, commercial fisheries, climate scientists, and industrial users. Similarly, surrogate relationships that use continuous monitoring to model time-series data for a parameter of interest can have the potential to add critical, but currently lacking, information at many sites with continuous and discrete data collection. As an example, total phosphorus can often be modeled from commonly measured continuous parameters such as turbidity, but it cannot be measured directly in situ at this time with commercially available instrumentation. Therefore, further exploration and use of surrogate modeling techniques with our existing datasets has the potential to expand our suite of parameters and locations with real-time and continuous data. Recommendation: The workshop participants recommend a further evaluation of opportunities to use existing continuous datasets in new ways that inform water-resource management and decision making. One example was a recent Powell Center workgroup that focused on using existing dissolved-oxygen data and developing new tools for data analysis to generate understanding of stream-primary productivity at a national scale. Studies that incorporate continuous monitoring data into models will be particularly valuable, because they extend the influence of sensor data to a larger spatial extent. 
Investments into new and innovative data analysis and visualization techniques will be needed to fully exploit high-resolution data.

3. Quantify the numerical uncertainty of continuous-monitoring data. Quantifying the uncertainty associated with continuous monitoring data has been an important need for some time. However, there are challenges associated with calculating and providing uncertainty data in real-time for many continuous monitoring measurements made by the USGS. The need is particularly timely given the desire to integrate data from multiple organizations across the country that collecting information on streamflow and water quality. Recommendation: The USGS and other organizations (including manufacturers) should standardize approaches to quantifying uncertainty in continuous data. Organizations such as the National Water Quality Monitoring Council Sensor Workgroup could participate or provide leadership on developing a multi-agency solution.

4. Make continued investments into the development and use of innovative technologies. Workshop participants had many ideas for future program expansion and examples of local to national success stories. Investments into the development and use of innovative technologies for continuous monitoring are often critical to those projects in order to meet the needs of the public or cooperator. Targeted funding of sensor and software design, testing, and operationsalong with techniques and methods for their standard operation-benefit the USGS and stakeholders. Recommendation: The USGS should continue to provide seed money through the USGS Innovation Center and Water Mission Area to help leverage existing projects and support the development and testing of promising technologies for water and earth sciences. Examples include, but are not limited to, early alert warnings for harmful algal blooms; sensors for eDNA identification; further development of sediment-acoustic techniques; techniques for large-scale particle image velocimetry; and methods for spatial integration through unmanned aerial vehicles (UAVs) and AUVs.

5. Coordinate network activities at local to national scales. The USGS operates large networks of continuous monitoring for measuring streamflow, groundwater levels, water quality, and other parameters. Many of these networks—-such as the 8,000 site streamgage network-form the backbone of our national real-time data for floods and droughts. However, integration of network activities at local to national scales and across disciplines of surface water, groundwater, and water quality will be critical to advancing the use of continuous monitoring for decision making. In particular, the use of continuous monitoring data to parameterize and validate regional to national models will continue to be important for describing the spatial variability in water quantity and quality across the Nation. The emergence of new tools to integrate, manage, and share large datasets is critical for the field of continuous monitoring to rapidly move forward. Recommendation: The USGS, Federal partners, and the broader community should continue to work towards integrated monitoring in water. The development of time-series techniques and tools for continuous monitoring may be readily shared across disciplines. Similarly, the integration into models such as the National Water Model (National Oceanic and Atmospheric Administration, 2016) will provide new information to guide management and policies designed to protect and restore our nation's water resources. 


\section{Acknowledgments}

This summary represents the efforts of many people who planned and participated in the workshop and we are grateful for their efforts. Special thanks should be given to the plenary speakers, training presenters, and participants in the technology demonstrations. In addition, we thank Eric Strom, Brian McCallum, and the staff at the South Atlantic Water Science Center for hosting the workshop and the workshop sponsors (U.S. Geological Survey (USGS) Office of Water Quality, USGS Office of Surface Water, and USGS Office of Groundwater).

\section{References Cited}

Bennett, T.J., Graham, J.L., Foster, G.M., Stone, M.L., Juracek, K.E., Rasmussen, T.J., and Putnam, J.E., 2014, U.S. Geological Survey quality-assurance plan for continuous water-quality monitoring in Kansas, 2014: U.S. Geological Survey Open-File Report 2014-1151, 34 p. plus appendixes, accessed January 10, 2018, at https://dx.doi.org/10.3133/ofr20141151.

Christensen, V.G., Jian, Xiaodong, and Ziegler, A.C., 2000, Regression analysis and real-time waterquality monitoring to estimate constituent concentrations, loads, and yields in the Little Arkansas River, south-central Kansas, 1995-99: U.S. Geological Survey Water-Resources Investigations Report 2000-4126, 36 p.

Christensen, V.G., Ziegler, A.C., and Jian, Xiaodong, 2001, Continuous turbidity monitoring and regression analysis to estimate total suspended solids and fecal coliform bacteria loads in real time, in The Federal Interagency Sedimentation Conference, 7th, Reno, Nev., 2001, Proceedings: Reno, Nev., Subcommittee on Sedimentation, v. 1, p. III-94 to III-101.

Durum, W.H., 1978, Historical profile of quality of water laboratories and activities, 1879-1973: U.S. Geological Survey Open-File Report 78-432, 110 p.

Jackson, P.R., 2013, Integrated synoptic surveys using an autonomous underwater vehicle and manned boats: U.S. Geological Survey Fact Sheet 2013-3018, 4 p.

Jackson, P.R., and Reneau, P.C., 2014, Integrated synoptic surveys of the hydrodynamics and waterquality distributions in two Lake Michigan rivermouth mixing zones using an autonomous underwater vehicle and a manned boat: U.S. Geological Survey Scientific Investigations Report 2014-5043, 33 p., accessed January 10, 2018, at https://dx.doi.org/10.3133/sir20145043.

Koltun, G.F., Eberle, Michael, Gray, J.R., and Glysson, G.D, 2006, User's manual for the Graphical Constituent Loading Analysis System (GCLAS): U.S. Geological Survey Techniques and Methods, book 4, chap. C1, 51 p.

Landers, M.N., Straub, T.D., Wood, M.S., and Domanski, M.M., 2016, Sediment acoustic index method for computing continuous suspended-sediment concentrations: U.S. Geological Survey Techniques and Methods, book 3, chap. C5, 63 p., accessed January 10, 2018, at https://dx.doi.org/10.3133/tm3C5.

Miller, M.P., Tesoriero, A.J., Capel, P.D., Pellerin, B.A., Hyer, K.E., and Burns, D.A., 2016, Quantifying watershed-scale groundwater loading and in-stream fate of nitrate using high-frequency water quality data: Water Resources Research, v. 52, no. 1, p. 330-347, accessed January 10, 2018, at https://doi.org/10.1002/2015WR017753.

Miller, M.P., Susong, D.D., Shope, C.L., Heilweil, V.M., and Stolp, B.J., 2014, Continuous estimation of base flow in snowmelt-dominated streams and rivers in the Upper Colorado River Basin-A chemical hydrograph separation approach: Water Resources Research, v. 50, no. 8, p. 6986-6999, accessed January 10, 2018, at https://doi.org/10.1002/2013WR014939. 
Myers, D.N., 2015, Foundations of water quality monitoring and assessment in the United States, in: Ahudja, Satinder, eds., Food, energy, and water-The chemistry connection (1st ed.): New York, Elsevier, p. 21-92.

National Oceanic and Atmospheric Administration, 2016, National Water Model-Improving NOAA's Water Prediction Services: National Oceanic and Atmospheric Administration, 2 p., accessed January 10, 2018, at http://water.noaa.gov/documents/wrn-national-water-model.pdf.

Oberg, Kevin, and Mueller, D.S., 2007, Validation of streamflow measurements made with acoustic Doppler current profilers: Journal of Hydraulic Engineering, v. 133, no. 12, p. 1421-1432.

Pellerin, B.A., Bergamaschi, B.A., Downing, B.D., Saraceno, J.F., Garrett, J.A., and Olsen, L.D., 2013, Optical techniques for the determination of nitrate in environmental waters: Guidelines for instrument selection, operation, deployment, maintenance, quality assurance, and data reporting: U.S. Geological Survey Techniques and Methods, book 1, chap. D5, 37 p.

Rasmussen, P.P., Gray, J.R., Glysson, G.D., and Ziegler, A.C., 2009, Guidelines and procedures for computing time-series suspended-sediment concentrations and loads from in-stream turbidity-sensor and streamflow data: U.S. Geological Survey Techniques and Methods, book 3, chap. C4, 52 p.

Toohey, R.C., Neal, E.G., and Solin, G.L., 2014, Guidelines for the collection of continuous stream water-temperature data in Alaska: U.S. Geological Survey Open-File Report 2014-1182, 34 p., accessed January 10, 2018, at http://dx.doi.org/10.3133/ofr20141182.

Topping, D.J., and Wright, S.A., 2016, Long-term continuous acoustical suspended-sediment measurements in rivers - Theory, application, bias, and error: U.S. Geological Survey Professional Paper 1823, 98 p., accessed January 10, 2018, at http://dx.doi.org/10.3133/pp1823.

Travis, A.S., 2002, Instrumentation in environmental analysis, 1935-1975, in Morris, P.J.T., eds., From classical to modern chemistry-The instrumental revolution: London, The Royal Society of Chemistry in association with the Science Museum, London and the Chemical Heritage Foundation, p. 285-308.

Uhrich, M.A., and Bragg, H.M., 2003, Monitoring instream turbidity to estimate continuous suspendedsediment loads and yields and clay-water volumes in the Upper North Santiam River Basin, Oregon, 1998-2000: U.S. Geological Survey Water-Resources Investigations Report 03-4098, 43 p.

Vonins, B.L., and Jackson, P.R., 2017, Response of currents and water quality to changes in dam operations in Hoover Reservoir, Columbus, Ohio, August 24-28, 2015: U.S. Geological Survey Scientific Investigations Report 2017-5027, 62 p., accessed January 10, 2018, at https://doi.org/10.3133/sir20175027.

Wagner, R.J.; Boulger, R.W., Jr.; Oblinger, C.J.; and Smith, B.A., 2006, Guidelines and standard procedures for continuous water-quality monitors - Station operation, record computation, and data reporting: U.S. Geological Survey Techniques and Methods book 1, chap. D3, 51 p. plus 8 attachments.

Wilson, Greg, Bryan, Jennifer, Cranston, Karen, Kitzes, Justin, Nederbragt, Lex, and Teal T.K., 2017, Good enough practices in scientific computing: PLoS Comput Biol 13(6), e1005510, https://doi.org/10.1371/journal.pcbi.1005510. 
Appendixes 1-4 


\section{Appendix 1. List of Participants}

[WSC, Water Science Center]

\begin{tabular}{|c|c|c|c|c|c|}
\hline First name & Last name & State & Affiliation & Email & Phone \\
\hline Francisco & $\begin{array}{c}\text { Almanzar- } \\
\text { Franqui }\end{array}$ & Florida & Caribbean-Florida WSC & $\begin{array}{l}\text { falmanzar- } \\
\text { franqui@usgs.gov }\end{array}$ & $787-674-5777$ \\
\hline Jessica & Anderson & Arizona & Arizona WSC & jranderson@usgs.gov & $928-556-7357$ \\
\hline Alison & Appling & Arizona & Office of Water Information & aappling@usgs.gov & $\begin{array}{l}520-670-6671 \times \\
271\end{array}$ \\
\hline Miya & Barr & Missouri & Central Midwest WSC & mnbarr@usgs.gov & $573-308-3552$ \\
\hline Joseph & Bell & Maryland & Maryland-Delaware-District of Columbia WSC & jmbell@usgs.gov & $443-498-5567$ \\
\hline Lee & Bodkin & Texas & South Atlantic WSC & ljbodkin@usgs.gov & $713-594-7704$ \\
\hline Amanda & Booth & Florida & Caribbean-Florida WSC & acbooth@usgs.gov & 239-293-0844 \\
\hline Michael & Canova & Texas & Texas WSC & mcanova@usgs.gov & 512-927-3536 \\
\hline Lisa & Carper & New Jersey & New Jersey WSC & lcarper@usgs.gov & $215-582-2468$ \\
\hline Мас & Cherry & Kansas & Ohio-Kentucky-Indiana WSC & macherry@usgs.gov & 502-649-6439 \\
\hline Fred & Day-Lewis & Connecticut & Branch of Geophysics & daylewis@usgs.gov & $860-487-7402$ \\
\hline Marian & Domanski & Illinois & Central Midwest WSC & mdomanski@usgs.gov & 217-819-6503 \\
\hline Bryan & Downing & California & California WSC & bdowning@usgs.gov & $916-278-3292$ \\
\hline Maureen & Downing-Kunz & California & California WSC & mdowning-kunz@usgs.gov & $916-278-3051$ \\
\hline Joe & Duris & Pennsylvania & Pennsylvania WSC & jwduris@usgs.gov & 717-730-6930 \\
\hline Sean & Egen & $\begin{array}{l}\text { North } \\
\text { Carolina }\end{array}$ & South Atlantic WSC & segen@usgs.gov & 919-571-4072 \\
\hline Christopher & Ellison & Montana & Wyoming-Montana WSC & cellison@usgs.gov & $406-431-0210$ \\
\hline Alexandra & Etheridge & California & California WSC & aetherid@usgs.gov & 916-995-0784 \\
\hline
\end{tabular}




\begin{tabular}{|c|c|c|c|c|c|}
\hline Joseph & Fleming & Arkansas & Arkansas WSC & jfleming@usgs.gov & $501-228-3609$ \\
\hline Guy & Foster & Kansas & Kansas WSC & gfoster@usgs.gov & $785-832-3525$ \\
\hline Ethan & Geisler & Virginia & Virginia-West Virginia WSC & egeisler@usgs.gov & $804-261-2602$ \\
\hline Jennifer & Graham & Kansas & Kansas WSC & jlgraham@usgs.gov & 785-832-3511 \\
\hline Kevin & Grimsley & Florida & Caribbean-Florida WSC & kjgrims@usgs.gov & $813-498-5064$ \\
\hline Andrew & Hickey & Georgia & South Atlantic WSC & achickey@usgs.gov & 678-924-6654 \\
\hline Ryan & Jackson & Illinois & Central Midwest WSC & pjackson@usgs.gov & 217-328-9719 \\
\hline John & Jastram & Virginia & Virginia-West Virginia WSC & jdjastra@usgs.gov & 804-261-2648 \\
\hline Thomas & Johnston & California & California WSC & tjohnston@usgs.gov & 916-591-8912 \\
\hline Brett & Johnston & Florida & Caribbean-Florida WSC & bjohnsto@usgs.gov & 321-239-4818 \\
\hline John & Joiner & Georgia & South Atlantic WSC & jkjoiner@usgs.gov & 678-924-6659 \\
\hline Heather & Krempa & Missouri & Central Midwest WSC & hkrempa@usgs.gov & $\begin{array}{l}816-554-3489 x \\
203\end{array}$ \\
\hline Justin & Kulongoski & California & California WSC & kulongos@usgs.gov & 619-225-6122 \\
\hline Mark & Landers & Georgia & Office of Surface Water & landers@usgs.gov & 678-924-6616 \\
\hline Michael & Lee & Texas & Texas WSC & mtlee@usgs.gov & 713-409-7878 \\
\hline Casey & Lee & Kansas & National Water-Quality Program & cjlee@usgs.gov & $785-832-3515$ \\
\hline Todd & Lester & Delaware & Maryland/Delaware/District of Columbia WSC & tlester@usgs.gov & $410-422-2489$ \\
\hline Jessica & Lucido & Wisconsin & Office of Water Information & jlucido@usgs.gov & $608-821-3841$ \\
\hline John & Lund & Minnesota & Upper Midwest WSC & jlund@usgs.gov & $612-790-0147$ \\
\hline Joseph & Martin & Connecticut & New England WSC & jwmartin@usgs.gov & $860-291-6752$ \\
\hline John & Mazurek & $\begin{array}{l}\text { North } \\
\text { Carolina }\end{array}$ & South Atlantic WSC & jmazurek@usgs.gov & 828-778-8508 \\
\hline Shannon & Meppelink & Iowa & Central Midwest WSC & smeppelink@usgs.gov & 319-430-5907 \\
\hline
\end{tabular}




\begin{tabular}{|c|c|c|c|c|c|}
\hline Matthew & Miller & Utah & Utah WSC & mamiller@usgs.gov & 801-908-5065 \\
\hline Craig & Mobley & Texas & Texas WSC & camobley@usgs.gov & 817-253-1000 \\
\hline Jon & Morrison & Connecticut & New England WSC & jmorriso@usgs.gov & 860-291-6761 \\
\hline Matt & Moser & Nebraska & Nebraska WSC & mmoser@usgs.gov & $402-328-4184$ \\
\hline Donna & Myers & Colorado & Office of Water Quality (retired) & dnmyers@usgs.gov & $303-236-6975$ \\
\hline Michael & Nyman & Texas & Texas WSC & mbnyman@usgs.gov & 210-691-9205 \\
\hline Kevin & Oberg & Illinois & Office of Surface Water (retired) & kaoberg@usgs.gov & 217-328-9739 \\
\hline Callie & Oblinger & Massachusetts & Water Science Field Team & oblinger@usgs.gov & 919-818-4670 \\
\hline Stephen & Opsahl & Texas & Texas WSC & sopsahl@usgs.gov & 210-691-9247 \\
\hline Colin & Peake & Illinois & Central Midwest WSC & cpeake@usgs.gov & 217-328-9729 \\
\hline Daniel & Pearson & Texas & Texas WSC & dpearson@usgs.gov & 512-927-3500 \\
\hline Brian & Pellerin & Virginia & Office of Water Quality & bpeller@usgs.gov & 703-648-6865 \\
\hline Patrick & Rasmussen & Kansas & Office of Water Quality & pras@usgs.gov & 785-832-3542 \\
\hline Teresa & Rasmussen & Kansas & Kansas WSC & rasmuss@usgs.gov & 785-832-3576 \\
\hline Jordan & Read & Wisconsin & Office of Water Information & jread@usgs.gov & 608-821-3922 \\
\hline Paul & Reneau & Wisconsin & Upper Midwest WSC & pcreneau@usgs.gov & $608-821-3901$ \\
\hline Manuel & Rosario & Puerto Rico & Caribbean-Florida WSC & mrosario@usgs.gov & 787-548-0755 \\
\hline Patricia & Sadler & $\begin{array}{l}\text { South } \\
\text { Carolina }\end{array}$ & South Atlantic WSC & pmsadler@usgs.gov & 803-727-9044 \\
\hline $\begin{array}{l}\text { John } \\
\text { Franco }\end{array}$ & Saraceno & California & California WSC & saraceno@usgs.gov & $916-278-3170$ \\
\hline Kimberly & Shaffer & Ohio & Ohio-Kentucky-Indiana WSC & kshaffer@usgs.gov & $614-430-7781$ \\
\hline Rodney & Sheets & Ohio & Water Science Field Team & rasheets@usgs.gov & $614-430-7710$ \\
\hline Lane & Simmons & Louisiana & Lower Mississippi-Gulf Water Science Center & lsimmons@usgs.gov & 225-978-4337 \\
\hline
\end{tabular}




\begin{tabular}{|c|c|c|c|c|c|}
\hline Cassandra & Smith & Oregon & Oregon WSC & cassandrasmith@usgs.gov & 503-251-3203 \\
\hline Teri & Snazelle & Mississippi & Hydrologic Instrumentation Facility & tsnazelle@usgs.gov & 228-688-1316 \\
\hline Dan & Sullivan & Wisconsin & Upper Midwest WSC & djsulliv@usgs.gov & $608-821-3869$ \\
\hline Peter & Tango & Maryland & Chesapeake Bay Program & ptango@chesapeakebay.net & 410-267-9875 \\
\hline Benjamin & Thepaut & $\begin{array}{l}\text { South } \\
\text { Carolina }\end{array}$ & South Atlantic WSC & bthepaut@usgs.gov & 843-855-1254 \\
\hline Wade & Walker & Colorado & Office of Water Information & walker@usgs.gov & 719-248-2101 \\
\hline Kelly & Warner & Illinois & Central Midwest WSC & klwarner@usgs.gov & 217-328-9727 \\
\hline Michelle & Wells & Alabama & Lower Mississippi-Gulf Water Science Center & mswells@usgs.gov & 205-348-0956 \\
\hline Scott & Wright & California & California WSC & sawright@usgs.gov & $916-278-3024$ \\
\hline Douglas & Yeskis & Virginia & $\begin{array}{l}\text { Groundwater and Streamflow Information } \\
\text { Program }\end{array}$ & djyeskis@usgs.gov & 217-714-1994 \\
\hline
\end{tabular}




\section{Appendix 2. Agenda}

[OWQ, Office of Water Quality; OSW; Office of Surface Water; WSC, Water Science Center; SAWSC, South Atlantic Water Science Center; AD, associate director; OGW, Office of Groundwater; WSFT, Water Science Field Team; TBD, to be determined; OWI, Office of Water Information; NWIS, National Water Information System; Q\&A, Questions and Answers; USGS, U.S. Geological Survey]

\begin{tabular}{|c|c|c|c|}
\hline Time & Day $1-$ Collecting continuous data & $\begin{array}{l}\text { Day 2-Understanding and } \\
\text { using continuous data }\end{array}$ & $\begin{array}{l}\text { Day 3-Observing and delivering continuous } \\
\text { data in the future }\end{array}$ \\
\hline $\begin{array}{l}\text { 8:30- } \\
\text { 9:00 }\end{array}$ & $\begin{array}{l}\text { Intros/Welcome } \\
\text { (Brian Pellerin, OWQ) Doug Yeskis } \\
\text { (WMA) }\end{array}$ & $\begin{array}{l}\text { Intros/Welcome } \\
\text { (Mark Landers, OSW) } \\
\text { Eric Strom (SAWSC Director) }\end{array}$ & $\begin{array}{l}\text { Intros/Welcome } \\
\text { (Rod Sheets, OGW) } \\
\text { Brian McCallum (SAWSC AD) }\end{array}$ \\
\hline \multirow{11}{*}{$\begin{array}{l}9: 00- \\
12: 00\end{array}$} & Plenary session & Plenary session & Plenary session \\
\hline & $\begin{array}{l}\text { 9:00: How technology innovations shaped the } \\
\text { development and delivery of } 21 \text { st century } \\
\text { real-time water-quality data (Donna Myers, }\end{array}$ & $\begin{array}{l}\text { 9:00: Collection and interpretation of various } \\
\text { frequencies of continuous groundwater-level } \\
\text { data (Rod Sheets, WSFT) }\end{array}$ & $\begin{array}{l}\text { 9:00: TBD (Don Cline, Water Mission Area- } \\
\text { remote presentation) }\end{array}$ \\
\hline & OWQ) & $9 \cdot 30$ : Interpreting continuous water-quality & $\begin{array}{l}\text { 9:30: Evaluating emerging technologies for } \\
\text { groundwater and surface water applications }\end{array}$ \\
\hline & $\begin{array}{l}\text { 9:30: Urban-hydrology programs in } \\
\text { metropolitan Atlanta (John Joiner, SA }\end{array}$ & $\begin{array}{l}\text { data to quantify spatial and temporal } \\
\text { variability in the source and transport of }\end{array}$ & (Fred Day-Lewis, Branch of Geophysics) \\
\hline & WSC) & $\begin{array}{l}\text { water and solutes at the watershed scale } \\
\text { (Matt Miller, Utah WSC) }\end{array}$ & BREAK (15 minutes) \\
\hline & BREAK (15 minutes) & & 10:15: Four dimensional continuous \\
\hline & 10:15: The Trials and Tribulations of Field- & BREAK (15 minutes) & $\begin{array}{l}\text { monitoring using mobile sensors (Ryan } \\
\text { Jackson, Illinois WSC) }\end{array}$ \\
\hline & $\begin{array}{l}\text { Validation Testing of Hydroacoustic } \\
\text { Instruments_-Lessons for the Future (Kevin } \\
\text { Oberg, OSW) }\end{array}$ & $\begin{array}{l}\text { 10:15: Continuous monitoring of suspended- } \\
\text { sediment and bedload transport in rivers } \\
\text { (Scott Wright, California WSC) }\end{array}$ & $\begin{array}{l}\text { 10:45: Integrated monitoring for harmful algal } \\
\text { blooms (Jennifer Graham, Kansas WSC) }\end{array}$ \\
\hline & $\begin{array}{l}\text { 10:45: Policies and best practices for } \\
\text { continuous data collection and archiving } \\
\text { (Callie Oblinger, WSFT) }\end{array}$ & $\begin{array}{l}\text { 10:45: Development and use of water-quality } \\
\text { surrogate models (Teresa Rasmussen, Kansas } \\
\text { WSC) }\end{array}$ & $\begin{array}{l}\text { 11:15: Innovations in data management: Next- } \\
\text { generation NWIS (Jessica Lucido, OWI) }\end{array}$ \\
\hline & & & Followed by Q\&A/discussion \\
\hline & Followed by Q\&A/discussion & Followed by Q\&A/discussion & \\
\hline
\end{tabular}




\begin{tabular}{|c|c|c|c|}
\hline $\begin{array}{l}12: 00- \\
1: 00\end{array}$ & Lunch/informal discussion & Lunch/informal discussion & Lunch/informal discussion \\
\hline \multirow{2}{*}{$\begin{array}{l}1: 00- \\
2: 00\end{array}$} & Demonstration & Demonstration & Demonstration \\
\hline & $\begin{array}{l}\text { Time-series workflows in AQUARIUS (Pat } \\
\text { Rasmussen, OWQ) }\end{array}$ & $\begin{array}{l}\text { Software for time-series data analysis (Alison } \\
\text { Appling, OWI; Marian Domanski, Central } \\
\text { Midwest WSC; John Franco Saraceno, } \\
\text { California WSC) }\end{array}$ & $\begin{array}{l}\text { USGS data science and visualization tools } \\
\text { (Jordan Read, OWI; Dan Pearson, Texas } \\
\text { WSC) }\end{array}$ \\
\hline \multirow{2}{*}{$\begin{array}{l}2: 00- \\
4: 30\end{array}$} & Technology “Hands-On” & Application Talks & Breakout Groups \\
\hline & $\begin{array}{l}\text { This will be an opportunity for USGS staff to } \\
\text { demo and discuss the operation of } \\
\text { continuous monitoring technologies } \\
\text { currently in use including sensors and data } \\
\text { collection platforms. }\end{array}$ & $\begin{array}{l}\text { This will be a series of short ( } 5 \text { minute) } \\
\text { "lightning" presentations on specific } \\
\text { applications of continuous monitoring data } \\
\text { for science and management. Discussion will } \\
\text { follow. }\end{array}$ & $\begin{array}{l}\text { Breakout groups will identify opportunities } \\
\text { and make recommendations on the future } \\
\text { collection and use of continuous monitoring } \\
\text { in the USGS. Reporting and wrap up will } \\
\text { follow. }\end{array}$ \\
\hline
\end{tabular}




\section{Appendix 3. Guidance Documents Pertinent to Continuous Monitoring}

[TM, Techniques and Methods report; OFR, Open-File Report; GCLAS, Graphical Constituent Loading Analysis System]

Topic

Link

Operation and maintenance

Guidelines and standard procedures for continuous water-quality monitors—Station operation, record computation, and data reporting

Optical techniques for the determination of nitrate in environmental waters—Guidelines for instrument selection, operation, deployment, maintenance, quality assurance, and data reporting

Optical techniques for the determination of fluorescence in environmental waters

Guidelines for the collection of continuous stream water-temperature data in Alaska

(Wagner and others, 2006)

TM 1-D5 (Pellerin and others, 2013)

Pellerin, B., USGS, written commun., 2017

OFR 2014-1182 (Toohey and others, 2014)

Data analysis

User's manual for the Graphical Constituent Loading Analysis System (GCLAS)

TM 4-C1 (Koltun and others, 2006)

Guidelines and procedures for computing time-series suspended-sediment concentrations and loads from in-stream turbidity-sensor and streamflow data

TM 3-C4 (Rasmussen and others, 2009)

Sediment acoustic index method for computing continuous suspended-sediment concentrations

TM 3-C5 (Landers and others, 2016)

Computing time-series concentrations and loads from in-situ sensor data

Rasmussen, T., USGS, written commun., 2017

Quality assurance

U.S. Geological Survey quality-assurance plan for continuous water-quality monitoring in Kansas, 2014

OFR 2014-1151 (Bennett and others, 2014) 


\section{Appendix 4. Policy Memos Pertinent to Continuous Monitoring}

[WRD, Water Resources Division; NWIS, National Water Information System; SSL, suspended sediment load; OSW, Office of Surface Water; Office of Water Quality; OGW, Office of Groundwater; WMA, Water Mission Area; USGS, U.S. Geological Survey; MAS, model archive summary]

\begin{tabular}{|c|c|c|c|}
\hline $\begin{array}{l}\text { Memo } \\
\text { source }\end{array}$ & Number & Title & Purpose \\
\hline WRD & 99.33 & $\begin{array}{l}\text { Preservation of Original Digital Field-Recorded } \\
\text { Time-Series Data }\end{array}$ & $\begin{array}{l}\text { This memorandum reaffirms existing policy requiring preservation of original } \\
\text { unaltered field data, with minor modifications to accommodate improved } \\
\text { digital data-collection technology. (Also: 92.59, 92.56) }\end{array}$ \\
\hline WRD & 99.34 & $\begin{array}{l}\text { Quality Assurance Measures for Serving Real-time } \\
\text { Water Data on the World Wide Web }\end{array}$ & $\begin{array}{l}\text { Establishes a policy for the implementation of quality-assurance measures for } \\
\text { real-time water data being served on the world wide web. (Also: } 95.19 \text { and } \\
\text { 97.17) }\end{array}$ \\
\hline OWQ & 2008.05 & Appropriate Data Storage in NWIS & $\begin{array}{l}\text { "Any water characteristic that is recorded automatically at intervals should } \\
\text { be...stored in NWIS...Policy differs by parameter whether...properly- } \\
\text { identified estimates may also be included” (OSW 90.11; Wagner and others, } \\
\text { 2006) }\end{array}$ \\
\hline WRD & 2010.02 & $\begin{array}{l}\text { Continuous Records Processing of all Water Time- } \\
\text { Series Data }\end{array}$ & $\begin{array}{l}\text { All Water Science Centers shall implement Continuous Records Processing of all } \\
\text { water time-series data by June 30, 2010, with the full understanding that it may } \\
\text { take some time for full implementation. }\end{array}$ \\
\hline OWQ & 2010.04 & $\begin{array}{l}\text { Publication of Techniques and Methods Report } \\
\text { Book 3, Chapter C4 “Guidelines and Procedures } \\
\text { for Computing Time-Series Suspended-Sediment } \\
\text { Concentrations and Loads from In-Stream } \\
\text { Turbidity-Sensor and Streamflow Data” }\end{array}$ & $\begin{array}{l}\text { The purposes of this memorandum are to: announce the on-line availability of } \\
\text { TM3-C4; provide policy with background information for use of turbidity as a } \\
\text { suspended-sediment surrogate to compute unit and daily records of suspended- } \\
\text { sediment concentrations and SSLs for subsequent storage in the NWIS, and } \\
\text { provide a synopsis of the guidelines and steps required to compute a } \\
\text { suspended-sediment record described in detail in the subject report. }\end{array}$ \\
\hline $\begin{array}{l}\text { OGW/ } \\
\text { OSW/ } \\
\text { OWQ }\end{array}$ & 2012.02 & $\begin{array}{l}\text { Policy for release of continuous water-temperature } \\
\text { data recorded from secondary sensors at } \\
\text { streamgages and wells }\end{array}$ & $\begin{array}{l}\text { This memo establishes policy and guidelines for quality assurance and review a } \\
\text { of water- temperature data from secondary thermistors. }\end{array}$ \\
\hline $\begin{array}{l}\text { OGW/ } \\
\text { OSW/ } \\
\text { OWQ }\end{array}$ & $\begin{array}{l}2015.02 / \\
2015.01\end{array}$ & $\begin{array}{l}\text { Policy and Guidelines for Archival of Surface- } \\
\text { Water, Groundwater, and Water-Quality Model } \\
\text { Applications }\end{array}$ & $\begin{array}{l}\text { The purpose of this memorandum is to create common requirements and policies } \\
\text { across the WMA and WMA-funded activities to maintain digital-model } \\
\text { archives. This policy applies to all models that are a significant part of } \\
\text { investigations reported in USGS interpretive publications, or other information } \\
\text { products. }\end{array}$ \\
\hline
\end{tabular}


OWQ

2016.09 Guidance for the Collection and Disposition of USGS Water-Quality-Data Records: Specifically Addressing Electronic Records for Field Notebooks and Calibration Notebooks

OSW/

OWQ

2016.07/ Policy and guidance for approval of surrogate regression models for computation of time-series suspended-sediment concentrations and loads

Policy builds on 2010.04 to require a model archive summary (MAS) approval for surrogate regression models for suspended sediment concentration and load.

\section{OGW/ 2017.01/ Clarification of Water Mission Area}

OSW/ 2017.05/ Policy on Continuous Records Processing of

OWQ 2017.02 Time-Series Data: Categorization of Groundwater, Surface Water, and Water-Quality Sites/Records
The purpose of this memorandum is to allow the use of electronic format for collection and archival of original water-quality-data records.

The purpose of this memorandum is to provide policy and guidance for developing and approving regression models used to compute high temporal frequency time-series suspended-sediment concentrations and loads from continuous turbidity or acoustic-backscatter data and continuous streamflow data that can be published without the need for documentation in a Bureauapproved interpretive report.

Water Science Centers should use the following guidance to ensure all time-series records and sites are properly categorized, especially ice-affected discharge records and furnished records.

This memo establishes new policy and procedures to identify and document revisions to USGS approved time-series and discrete water data. 